\title{
Refusal Strategies Among Sundanese Students: An Analysis of Gender and Power Relation
}

\author{
Rahmatillah Solihah, Ernie D.A.Imperiani \\ Departement of English Education \\ Universitas Pendidikan Indonesia \\ Bandung, Indonesia \\ rahama0503@gmail.com
}

\begin{abstract}
This study aims to investigate the contribution of power relations to the realization of refusal strategies done by Sundanese male and female students. This study employs a descriptive qualitative approach. The data used in the present study were gathered from a Discourse Completion Test (DCT) that was distributed to 4 male and 4 female respondents. The data were analyzed by using Beebe, Takahashi, and Uliss-Welts's (1990) classifications of refusal. The findings show that there is no substantial difference in terms of the strategies employed by both genders. It is also found that power relation influences the realization of refusal. This finding suggests that when the respondents refuse someone who is more powerful, they tend to prioritize the emotional feeling of the requester. Meanwhile, when the respondents refuse someone who is more powerless, they tend to prioritize things by using their logic
\end{abstract}

Keywords: gender, power relation, refusal, Sundanese

\section{INTRODUCTION}

Refusal is one of the speech acts that is mostly used by people in any language. According to Aziz (2000 as cited in Septiany, 2013), refusal is a directive response of directive speech acts such as offer, invitation, request, argument, suggestion, and command. For several reasons, understanding the studies of refusal is important since the act of refusal always occurs in everyday communication. Moreover, refusal strategies have to be employed properly to minimize errors in communication.

There have been studies conducted to investigate the acts of refusal in certain languages. Al-Mahrooqi and Al-Aghbari (2016) investigated the refusal strategies among Omani EFL students, Abarghoui (2012) who analyzed a comparison of refusal strategies used by Iranians and Australians and Guo (2012) who explored a comparison of refusal strategies used by Chinese and American. With regard to studies refusal in Indonesia, Aziz (2000 as cited in Muniroh, 2013) observed that the study of refusal is based on the trend of Indonesians who do not speak openly, preferring to express their feeling, thoughts and ideas indirectly which is confirmed by others such as
Septiany (2013); Chojimah, (2015); Nurweni, Sudirman and Mahpul, (2016).

Although there have been studies investigated the issue of refusal in Indonesian context, the issues about realization of refusal strategies which involve ethnic groups in Indonesia have not received much attention. This study attempts to fill the gap by investigating the contribution of power relation to the realization of refusal strategies done by Sundanese male and female students on the refusal in power relation and gender context.

There are two kinds of speech acts of refusals, which are direct and indirect. As Brown and Levinson (1987) suggest that the speakers can use strategies such as directness, indirectness, and polite states in order to avoid quarrels. Meanwhile, Searle (1975 as cited in Hedayatnejad, Maleki \& Mahrezi, 2016) states that speakers use a direct speech act to convey literal meanings. In terms of indirect refusal, the speaker has to select the appropriate form(s) to decrease the negative influence of a direct refusal (Hedayatnejad \& Rahbar, 2014). The classification of refusal has been introduced by some researchers. One of the classifications of refusal strategies was examined by Rubin (1983) and his study states that there are nine ways of refusing.

However, the most commonly known semantic formulas in refusal strategies are based on Takahashi and Beebe et al's (1990) classification: direct and indirect refusal. The direct refusals are divided into two: performative verbs such as 'I can't', and non-performatives like 'no'. The indirect refusals consist of various types: such as statement of regret, wish, and excuse, statement of alternative, refusal, and adjuncts to refusal.

Bebee et al. (1990) classification strategies include the semantic formula that can be used in refusal to different speech acts; for example, invitations, requests, offers and suggestions. However, it should be noted that not all of these strategies may necessarily be used to respond to each of the eliciting speech acts.

Power is a social variable that is related to the positions and status of certain people. According to Gray (2009), power is a 
complex social variable which is determined by different social and individual factors. Meanwhile, Brown and Levinson (1987) argue that power determines speaker and hearer's plans and selfevaluation. It means that some people can accept or reject a specific action proposed to him or her based on the power.

In the present study, there are three types of power employed. First is interaction between the powerless refuser and powerful refusee ( $\mathrm{L}$ to $\mathrm{H}$ ). Second is between powerful refuser and powerless refusee ( $\mathrm{H}$ to $\mathrm{L})$. Last is between the refuser and refusee who possess equal power.

According to Holmes and Lakoff (1995), gender and speech acts are interwoven to each other (as cited in Hedayatnejad \& Rahbar 2014). Similarly, Abarghoui (2012) claims that gender and speech behavior are interrelated variables.

With regard to refusal in Sundanese, Mulyani (2013) explored two types of realizations of making refusal in Sundanese context. The finding shows that the realization of making refusals in Sundanese is grouped into two: expressed in indirectness by employing saving face, and expressed in indirectness by employing both saving and losing face. Additionally, Sukmawan and Darmayanti (2014) deal with refusal in spoken language of daily conversation of Sundanese society in Sukabumi. The result shows that the Sundanese community in their research did not indirectly refuse on certain requests. It implies that refusal realization reflects Sundanese society as a society who is always concerned with politeness in speech activity especially in refusal.

\section{METHOD}

The method used in the present study is qualitative descriptive. It involved 8 Sundanese college students (4 males and 4 females), ranging in age from 19 to 23 years old. Research data were collected by using a written Discourse Completion Test (DCT) adopted from Moaveni's (2014) study of refusal translated into Bahasa Indonesia. The DCT consisted of 6 situations, and they were classified into different power relation: low-to-high, high-to-low, and equal.

The reliability and validity of the DCT had already been established in Moaveni's (2014) study. However, the DCT was checked in the field for face validity by experts.

\section{FINDINGS AND DISCUSSION}

As proposed by Beebe et al. (1990), there are three classifications of refusal strategies, namely direct refusal, indirect refusal, and adjuncts to refusals. From the data observed, the strategies applied are not significantly different in both genders. They applied strategies in the same way. The more powerful the refusee faced by the refuser is, the more both genders tend to use statement of regret first in expressing the refusal. Meanwhile, the more powerless the refusee is, the more males and females tend to use Excuse, reason, and explanation strategy.

\section{Power Relation and the Realization Refusal Strategies}

In this study, there are three classifications of power relations which are engaged in the DCT. The first is between the powerless refuser and powerful refusee (Low to High). The second is between the powerful refuser and the powerless refusee (High to Low). Last, it is between the refuser and the refusee who are equal in terms of power.

The first category of power relation is between powerless refuser and powerful refusee. As can be seen in Table I, there are no considerable differences between Sundanese male and female students in refusing powerful refusee. This finding is similar to Hetnayajad, Maleki and Mahrezi (2012) that found the frequency of applied strategies in refusal is not statistically different between the female and male participants in each levels of social status and power. In the present study, both genders tend to use statement of regret first to refuse powerful refusees in expressing the refusal as illustrated in Table I. below.

TABLE I. REFUSAL STRATEGIES BETWEEN L - H RELATION

\begin{tabular}{|c|c|c|c|c|c|}
\hline \multirow{3}{*}{ Strategies } & \multicolumn{2}{|c|}{ Respondents } & \multicolumn{3}{|c|}{ Total } \\
\hline & \multirow{2}{*}{ Male } & \multirow{2}{*}{ Female } & \multirow{2}{*}{$\begin{array}{c}\text { Over- } \\
\text { all } \\
\text { Freq. }\end{array}$} & \multicolumn{2}{|c|}{ Percentage (\%) } \\
\hline & & & & Male & Female \\
\hline Non-performative & 6 & 5 & 11 & 12.50 & 10.20 \\
\hline Statement of regret & 7 & 8 & 15 & 14.58 & 16.32 \\
\hline $\begin{array}{l}\text { Excuse, } \\
\text { explanation }\end{array}$ & 6 & 6 & 12 & 12.50 & 12.50 \\
\hline Statement of alternative & 3 & 2 & 5 & 6.25 & 4.16 \\
\hline $\begin{array}{l}\text { Promise of future } \\
\text { acceptance }\end{array}$ & 2 & 1 & 3 & 4.16 & 2.03 \\
\hline Pause filler & 1 & 1 & 2 & 2.03 & 2.03 \\
\hline Total & 25 & 23 & 48 & & 00 \\
\hline
\end{tabular}

The table above is between the $\mathrm{L}-\mathrm{H}$ relation. The frequency of strategies applied is not considerably different in both genders. There are six (out of 8) strategies found. As the table demonstrated, Statement of regret strategy is the most common strategy used by male and female students. Following Statement of regret strategy, there is Excuse, reason, explanation strategy. Therefore, in the $\mathrm{L}-\mathrm{H}$ relation, males and females tend to use Statement of regret as the first strategy, then excuse, reason, explanation is employed in the last strategy. The illustration is taken from situation 4 and 5 in which the refuser has to refuse a request from lecturer. The answer is as follows.

M3 : Hapunten bu (regret), kangge pelajaran tambahan senen enjing teh jigana abdi teu tiasa ngabantosan (non performative) kumargi nuju teu raraos(reason). Kin abdi komunikasi deui ka adi tingkatna,mungkin reschedule bu (statement of alternative).

'I'm sorry Ma'am, regarding the additional lesson tomorrow, likely I couldn't help you because I am feeling sick. I'll talk about it later with my junior. I think it will be rescheduled for another time.

F3: Punten pak (regret), simkuring teu tiasa ngaluuhan uleman ti bapak (non performative) margi simkuring ngaraos anyar keneh (reason), ngkin pasti dongkap upami tos waktosna(promise of future acceptance) 
'I'm sorry sir, I can't attend your invitation because I am still freshman here, I'll come in another time'

The employment of semantics formula of the refusal strategies in this $\mathrm{L}-\mathrm{H}$ relation shows several ideas. When M3 and $\mathrm{F} 3$ refuse a request from powerful person, they will show regret to the refuse first. It indicates that males and females will prioritise emotional feeling of the refusee first. It means that the refuser will be more comfortable in conveying refusal since they refuse a powerful person. Hatam (2014) States that hearing a refusal results in disappointment at the beginning, so the speaker should do his/her best to decrease the disappointment by using phrases like 'I'm (so) sorry. furthemore, males and females want to show their respect towards the refusee who is more powerful than them. This idea is illustrated from the employment of Statement of regret strategy.

This strategy is also softened by using an address term. Since the person who was refused is a lecturer, the usage of ' $\mathrm{Bu}$ or Pak' is usual for Sundanese participants. Afterwards, it is found that males and females avoid direct strategies like (no). According to Sattar, Che lah and Sulaeman (2011), saying 'no' to someone's face means as an insult to the other person. Instead, the respondents here used 'negative ability' by using I can't. Similarly, Félix-Brasdefer (2002) point out that the low use of the directness (flat no) to refuse the higher power interlocutor can save hearer's positive face.

Then, the use of those six strategies also indicates that males and females do not want to make the refusees disappointed because they are unable to fulfil their requests. This idea is viewed from the usage of Excuse, reason, explanation and Statement of alternative strategy.

Additionally, it is also found that the refusers do not want to break or harm the trust of refusee by providing statement of alternative and promise of future acceptance strategy. With regards to speech level in Sundanese, both genders used refined language which is called Bahasa lemes in Sundanese. According to Sudaryat (2007), Bahasa lemes is usually used when people talk to a powerful person.

The next power relation discussed is between a powerful refuser and a powerless refusee $(\mathrm{H}-\mathrm{L})$. As can be seen from the Table I, males and females tend to use excuse, reason, and explanation strategy. However, different with females, males tend to use less an apology or statement of regret strategy.

The illustration of how the powerful refuser refuses requests from the powerless refusee is provided in the form of Table II. In this $\mathrm{H}-\mathrm{L}$ relation, it is found that the respondents employed seven strategies of refusal. Excuse, reason, explanation strategy is the most used strategy employed by both genders. However, the differences found when males and females employed the second and the third strategy. The second most used refusal strategy by females is Non-Performative while promise of future acceptance becomes the second most used refusal strategy by males. Afterwards, the third strategy employed by females is statement of regret while males employed Non-Performative strategy.
TABLE II. REFUSAL STRATEGIES BETWEEN H - L RELATION

\begin{tabular}{|c|c|c|c|c|c|}
\hline \multirow{3}{*}{ Strategies } & \multicolumn{2}{|c|}{ Respondents } & \multicolumn{3}{|c|}{ Total } \\
\hline & \multirow[b]{2}{*}{ Male } & \multirow[b]{2}{*}{ Female } & \multirow{2}{*}{$\begin{array}{c}\text { Over- } \\
\text { all } \\
\text { Freq. }\end{array}$} & \multicolumn{2}{|c|}{ Percentage (\%) } \\
\hline & & & & Male & Female \\
\hline Non-performative & 5 & 5 & 10 & 10.20 & 10.20 \\
\hline Statement of regret & 2 & 5 & 7 & 4.08 & 10.20 \\
\hline $\begin{array}{l}\text { Excuse, reason, } \\
\text { explanation }\end{array}$ & 8 & 8 & 16 & 16.32 & 16.32 \\
\hline $\begin{array}{l}\text { Statement } \\
\text { alternative }\end{array}$ & 1 & 2 & 3 & 2.40 & 4.08 \\
\hline $\begin{array}{l}\text { Promise of future } \\
\text { acceptance }\end{array}$ & 6 & 2 & 8 & 12.24 & 4.08 \\
\hline Pause & 1 & 3 & 4 & 2.40 & 6.12 \\
\hline Avoidance & 1 & & 3 & 2.40 & 0 \\
\hline Total & 24 & 25 & 49 & 100 & \\
\hline
\end{tabular}

Below is the illustration of the respondents of $\mathrm{H}-\mathrm{L}$ relation. The situation involves a junior who asked a senior to check his paper.

F4 : $\quad$ Nuju seueuer tugas eung, kudu bikin chapot jeung presentasi oge, 3 matkul deuih barengan (reason). Maafin pisan (regret) gak bisa ngabantuan(non-performative).

'I have many assignments, I have to make chapter report and prepare for presentation, three tasks at once. I'm sorry I can't help you'

M2 : keur ngerjakeun tugas euy (reason), teu bisa jigana (non performative), ke we lamun sempet (promise of future acceptance)

'I'm doing an assignment right now, it seems like I can't, I'll do it if I have time'

The example shows that when F4 and M2 refused a request from a powerless requester, they provided reason or explanation first instead of expressing her regret to the refusee. In other words, males and females tend to prioritize things by using their logic first and put the emotional feeling of the refusee afterwards. M2 also provided reason or explanation strategy first but employed promise of future acceptance strategy in the last statement. It indicates that males prioritizes logical things first and try not to break or harm the trust by using promise of future acceptance strategy. Different with females, males do not seem to be too concerned with emotional feeling of the requesters because they use less statement of regret strategy. Furthermore, both genders also employed non performative strategy by using 'I can't' to make their stand clearly. According to Saad, Bidin and Shabdin (2016), the word I can't as direct strategy indicate their stand clearly.

Additionally, in this H-L relation, when females employed excuse, reason, and explanation strategy, they employed the complex reason rather than males. Females tend to put more than one reasons to convince the refusee that they can't fulfil their request because they have something urgent to do.

With regards to speech level in Sundanese, both genders used middle language or in Sundanese it is called Bahasa loma. According to Sudaryat (2007), Bahasa loma is usually used when people talk to someone who is powerless or someone who has equal power. 
The last category in this study is the equal power relation. In other words, the refuser and the refusee are the same in terms of power. It involves the interactions between the respondents and their classmates. According to the table, the most used strategy employed by males and females is non performative strategy (Table III).

TABLE III. REFUSAL STRATEgIES BETWEEN EQUAL POWER RELATION

\begin{tabular}{|c|c|c|c|c|c|}
\hline \multirow{3}{*}{ Strategies } & \multicolumn{2}{|c|}{ Respondents } & \multicolumn{3}{|c|}{ Total } \\
\hline & \multirow{2}{*}{ Male } & \multirow{2}{*}{ Female } & \multirow{2}{*}{$\begin{array}{c}\text { Over- } \\
\text { all } \\
\text { Freq. }\end{array}$} & \multicolumn{2}{|c|}{ Percentage (\%) } \\
\hline & & & & Male & Female \\
\hline Non-performative & 9 & 8 & 17 & 17.30 & 15.38 \\
\hline Statement of regret & 5 & 5 & 10 & 9.61 & 9.61 \\
\hline Excuse,reason,explanation & 8 & 5 & 13 & 15.38 & 9.61 \\
\hline Statement of alternative & 2 & 1 & 3 & 3.84 & 1.92 \\
\hline $\begin{array}{l}\text { Promise of future } \\
\text { acceptance }\end{array}$ & 3 & 1 & 4 & 5.76 & 1.92 \\
\hline $\begin{array}{l}\text { Acceptance functioning as } \\
\text { refusal }\end{array}$ & 0 & 1 & 1 & 0 & 1.92 \\
\hline Pause filler & 3 & 2 & 5 & 4.28 & 2.28 \\
\hline Total & 30 & 22 & 52 & 100 & \\
\hline
\end{tabular}

As the table demonstrates, males employed more strategies rather than females. Non-Performative strategy is the most widely used strategy in this equal power relation between both genders. Following non-performative, there are Excuse, reason and explanation and Statement of regret strategies. Below is the example. The situation involves someone who asked his friend to watch football competition with him.

\section{M3: Hampura daks (regret)sigana gak akan datang euy(non performative), saya mau pergi. Biasa urusaneun(reason)}

' I'm sorry, it seems like I can't come, I have to go. I have another business'

F3: hampura ih (regret) aku gak bisa dateng (nonperformative), tugas aku banyak jeung numpuk sedangkan deadline nya besok(reason)

'I'm sorry, I can't come. There are so many assignments and tomorrow is the deadline.

Several things can be noted from the data above. When equal refuser refused a request from equal requester, M3 and F3 tend to provide statement of regret first, and use the direct non performative by saying 'I can't'; after that, they provide reason or explanation strategy in the last statement. This finding is in line with Sattar et al. (2011) finding that claims people who are of equal power tend to refuse the request with following semantic formula; Regret, negative ability, and explanation or reason strategy. This semantic formula is similar to $\mathrm{L}-\mathrm{H}$ relation. Males and females are concerned with the emotional feeling of the requester first, and put logical thing to convince the requester. However, some differences are found in the speech level of communication in Sundanese. In L-H relation, the respondents use refined language (Bahasa lemes), while in this equal relation, males and females used middle language (Bahasa loma). It can be seen when males and females employ the apology strategy. They used the word 'hampura', instead of 'punten', which is less polite in sundanese.

From all strategy that both genders employed related to 3 power relations, male and female students are considered to be polite in refusing since they use indirect strategies and contain apologizing and expressing regret. Hatam (2014) states that the use of indirect strategies, such as apologizing, shows the politeness degree of the refusal. Additionally, these refusals in the present study also contain post-refusals like promise for future acceptance strategy which decrease the threat of refusal (Levinson, 1997 cited in Hatam, 2014).

In addition, based on the illustrations above, this study indicates that the Non-performative strategy is never used at al by the participants as the only strategy to refuse request. In other words, the use of that strategy is always combined with indirect refusal strategies.

\section{CONCLUSION}

The study shows that there are no considerable differences between Sundanese males and females in the realization of refusal in three level of power relation. It is revealed that more power of the requesters tends to lead both genders to use the statement of regret strategy in refusal. It indicates that males and females prioritize the emotional feeling of the refusee. In this context, an expression of regret is the mitigator of the dissapointed effect of a refusal. Additionally, it is also found that less power of the requesters tends to lead both genders to use the excuse, reason, explanation strategy. It indicates that males and females tend to prioritize things by using their logic.

\section{REFERENCES}

Abarghoui, M. A (2012). A comparative study of refusal strategies used by Iranians and Australians. Theory and Practice in Language Studies, 2(16), 2439-2445. doi: 10.4304/tpls.2.11.2439-2445

Al-Mahrooqi, R., \& Al-Aghbari, K. (2016). Refusal strategies among Omani EFL students. Sage journal, 1-10. doi: $10.1177 / 2158244016672907$

Beebe,L. M., Takahashi, T. \& Uliss-Welts, R. (1990). Pragmatic transfer in ESL refusals. In: Anderson, E., Krashen, S and Scarella, R. (Eds.). Developing communicative competence in a second language, Newbury House, New York, 55-73.

Brown, P., \& Levinson, S. C. (1987). Politeness: Some universals in language usage (Vol. 4). Cambridge university press.

Chojimah, N. (2015). Refusal and politeness strategies in relation to social status: a case of face-threatening act among Indonesian University students. Theory and Practice in Language Studies, 5(5), 906. doi: 10.17507/tpls.0505.04

Félix-Brasdefer, J. C. (2006). Linguistic politeness in Mexico: Refusal strategies among male speakers of Mexican Spanish. Journal of Pragmatics, 38(12), 10.1016/j.pragma.2006.05.004
2158-2187.

doi 
Guo, Y (2012). Chinese and American refusal strategy: A crosscultural approach. Theory and Practice in Language Studies, 2(2), 247-256. doi: 10.4304/tpls.2.2.247-256

Gray, K. M (2009). Politeness in increasing degree of imposition: A sociolinguistic study of politeness in political conversation. Unpublished master thesis, Departement of Linguistics the University of Utah, U. S.

Hedayatnejad, F., Maleki R., \& Mehrezi, A (2016). The effect of social status of gender on realization of refusal of suggestion among Iranian EFL Intermediate learners. Journal of Language Teaching and Research, 7(1), 99-109. doi: 10.17507/j1tr.0701.11

Hedayatnejad, F., \& Rahbar, B (2014). The effect of gender on realization of refusal of suggestion in formal and informal situation among Iranian EFL learners. International Journal for Teachers of English, 4(6), 20-43. doi: 10.18844/gjs.v5i1.52

Moaveni, H. T. (2014). A study of refusal strategies by American and International Students at an American University. Unpublished master thesis. Minnesota State University, Mankato.

Mulyani, E. R., (2013). Two type of realization of making refusal in sundanese context: A case study. Journal of English Language Teaching in Indonesia, 1(1), 11-22.

Muniroh, R. D. D (2013). Follow-up responses to refusals by Indonesian learners of English as a foreihm language. Indonesian Journal of Applied Linguistics, 2(2). 281-293. doi: 10.17509/ijal.v2i2.172
Nurweni, A., Sudirman, S., \& Mahpul, M. (2016). Indonesian senior high school students'refusal strategies in efl classes. PROSIDING PRASASTI, 165-170. Rubin, J (1981). How to tell when someone is saying 'no' revisited. National Institute of Education (ED): Washington, DC

Saad, N., Bidin, S. J., \& Shabdin, A. A. (2017). Refusal strategies used by malay esl studentsand english native speakers to refuse a request. Proceedings of the ICECRS, 1(1), 253-266. doi: 10.21070/picecrs.v1i1.609

Sattar, H. Q. A., Lah, S. C., \& Suleiman, R. R. R. (2012). Refusal strategies in English by Malay university students. GEMA Online ${ }^{\circledR}$ Journal of Language Studies, 11(3). 69-81.

Septiany, A. (2013). The realization of refusal strategies by parents and children in the family domain. Indonesian Journal of Applied Linguistics, 1(1), 133-146.

Sukmawan, R., \& Darmayanti, N. (2014). The expression of refusals in the utterance of west java sundanese society. International iournal of language learning and applied linguistics world, 5(1), 345-355.

Sudaryat, Y. (2007) Kesantunan berbahasa sunda sebagai landasan membangun karakter bangsa retrieved from www.journal.uinsgd.ac.id/index.php/jat/article/download/1794/ 1193 